\title{
Influence of Remuneration and Tenure on Auditors' Independence in Nigeria
}

\author{
${ }^{1}$ J. K. Olowookere , ${ }^{2}$ M.O. Oladejo \\ ${ }^{1,2}$ Department of Management and Accounting Ladoke Akintola University of Technology, Ogbomoso
}

\begin{abstract}
For many years now, accounting regulators have had concerns about the possible lack of independence between auditors and their clients arising from a long standing professional relationship. The issue is that auditors might get too close to their clients and can lose profession skepticism and objectivity when the relationship goes on too long. This study investigated the influence of remuneration and tenure on auditors' independence in Nigeria. The study used primary and secondary data which was collected by administered a well structure questionnaire. The findings of the study showed thatthe provisions in the Company and Allied Matters Act (2004) are not sufficient to ensure auditors' independence in Nigeria and in very many situations auditors in Nigeria were allowed to serve their clients for more than one accounting year. The study concluded that auditors' remuneration and tenure should be taken into consideration by the regulatory bodies in ensuring auditors' independence in Nigeria.
\end{abstract}

Keywords: CAMA, Auditors, Auditors' independence, Remuneration and Tenure.

\section{Introduction}

The importance of auditor independence in fact and in appearance, is widely accepted in theory and practice (Nelson, 2006). Auditor independence has been traditionally viewed as the cornerstone of the auditing profession as it being one of fundamental principles underlying the auditors' work (Firth,1980). Researchers argue that permitting an unlimited period of association between audit firms and their clients threats independence (Moore, Tetlock, Tanlu and Bazerman 2006; Raiborn, Schorg and Massoud, 2006). There is no limit to the number of years external auditors in Nigeria could be re-appointed in the Companies and Allied Matters Act CAP. C20. LFN 2004. Under the Companies Act, a company may only engage an auditor for one year. However, in practice firms are frequently and repeatedly reappointed. For instance, Akintola Williams Deloitte formally resigned as the auditor of Cadbury Nigeria Plc. after 41 years as their external auditors. In UK, Barclays Bank has not changed their auditors since incorporated over 100 years ago (Chamber, 2011). Currently, there are no rules on how long an accounting firm can serve as an auditor for a company. The average auditor tenure is 22 years (GAO 2003). KPMG has been the external auditor of record for General Electric for over a century. Deloitte and Touche has been the auditor for General Motor for over eighty five years (Mason, 2004). Presently, section 203 of the Sarbaners-Oxley Act (SOX) requires audit partner rotation but it does not require audit firm rotation.

Regulatory framework in professional audit practice is an important requirement to maintain standard and development in any profession. In order to protect auditor's independence, the regulatory frameworks of many countries include regulations and guidelines which auditors are required to observe. The credibility of financial statements prepared by directors of limited liability companies and audited by external auditors remains the primary means of informing shareholders and other stakeholders about the financial performance, progress and position of the business (Tahinakis and Nicolaou, 2004; Okike, 2004; Bakre, 2007; Sikka, Fillings and Liew, 2009; Dabor and Adeyemi, 2009; Evbodaghe, 2009).

\subsection{Statement of the Problem}

External auditors play important roles in capital markets by providing services that protect the interest of the investing public. This public watching function requires that accounting firms remain independent of the audit client and act on behalf of the public, not the client. However, the control over hiring and firing auditors by client management combined with managers' strong motivation to attain or exceed stated goals and objectives imposes a heavy burden upon the auditor to stand firm. According to Abdel-Khalik (2002), the biggest fallacy in corporate governance today is the premise that Shareholders elect and appoint the auditor. Shareholders (through proxy votes) have effectively handed over the control of auditor-related decisions (hiring, retention and compensation) to management. Therefore, the real motivation for auditor-client re-alignment might be known only to management. Onwuchekwa, Erah and Izedonmi (2012) argue that, where this happens, the auditor will have to dance to the tune of the directors as they may not want to bite the very hands that fed them even if it means compromising their independence. There is a widespread public perception that auditors lack independence from company executives and as a result, there are concerns about the quality of audits 
(Evbodaghe, 2009 and Sikka, Filling and Liew, 2009).The contemporary auditing model makes audits to be dependent on companies and their directors for fees and profits. This model is further complicated by the fact that auditors are permitted to sell other accountancy services to their audit clients (Otunsanya, and Lauwo, 2010). The coziness of the auditor-client relationships has been identified as the major reason in which has disappear the renowned audit firm, Arthur Andersen from the accounting globe and the reputation of the entire profession was tarnished (Lennox, 2005). According to Bazerman, Morgan and Loewenstein (1997), since auditors are paid by their clients, it is "psychologically impossible for an auditor to be free from bias."

The broad objective of this study is to appraise the effects of remuneration and tenure on auditors' independence in Nigeria.

The specific objectives of the study are to:

i) investigate the level of compliance by quoted companies with the provisions of the Companies and Allied Matters Act 2004 in the appointment and remuneration of auditors in Nigeria;

ii) assess the extent to which remuneration and tenure affect auditors' independence in Nigeria.

\subsection{Hypotheses of the Study}

For the purpose of this study, two testable hypotheses were formulated and tested.

$\mathrm{H}_{01} \quad$ There is no significant relationship between auditors' tenure and audit fees in Nigeria.

$\mathrm{H}_{\mathrm{a} 1} \quad$ There is significant relationship between auditors' tenure and audit fees in Nigeria.

$\mathrm{H}_{02}$ There is no significant relationship between auditors' remuneration and auditors' independence in Nigeria.

$\mathrm{H}_{\mathrm{a} 2} \quad$ There is significant relationship between auditors' remuneration and auditors' independence in Nigeria.

\section{Literature Review}

The concept of 'independence of the auditor' refers to the necessity of the auditor being not under the influence of his client or appointing authority (Kumar and Sharma, 2009). Expression of independent opinion on the financial statements by an appointed auditor is the most basic objective of an audit. An auditor should prove himself to be an independentperson and must not compromise on important issues with his appointing authorities. His reports lend credibility to the financial information upon which reliance can be placed by the users of financial statements. The state of being impartial and free from bias and conflict of interest is an important one in auditing, as Woolf (1986) argues:

The concept of audit and the concept of independence are the twin sides of the same coin. The auditor who has lost his independence has lost his raison detre; he has become, dependent ${ }^{\text {ee }}$ and a dependent ${ }^{\text {ee }}$ auditor is a contradiction in terms.

Similarly, Millichamp (2002) argues that "not only must the auditor be independent in fact and in attitude of mind, but he must also be seen to be independent."

Nevertheless, in defining auditor independence, the literature selects objectivity, the ability to avoid biases; and integrity, willingness to report a truthful opinion that reflects the matters discovered during the audit (DeAngelo, 1981). Despite all the definitions and descriptions of auditors'independence, Whillington and Pany (2004) concluded that auditor independence is relative and not absolute.

In Nigeria, there is no limit to number of years external auditors can serve as auditors of listed companies. The only exception to this rule is the Code of Corporate Governance issued by CBN in 2006 giving a maximum period of 10 years after which the audit firm shall not be re-appointed in the bank until after a period of another 10 years (CBN, 2006).Section 357(1) of the Companies and Allied Matters Act CAP.C20 LFN, 2004 provides that every company shall at each annual general meeting appoint an auditor or auditors to audit the financial statements of the company and to hold office from the conclusion of that, until the conclusion of the next, annual general meeting.Section 357(2) also provides that at any annual general meeting, a retiring auditor (out-going), however, appointed shall be re-appointed without any resolution being passed unless: (a) he is not qualified for re-appointment; or (b) a resolution has been passed at that meeting appointing some other persons instead of him or providing expressly that he shall not be reappointed; or (c) he has given the company notice in writing of his unwillingness to be reappointed. Section 357(3) provides that where at an annual general meeting, no auditors are appointed or re-appointed, the directors may appoint a person to fill the vacancy.

Olagunju (2011) carries out an analysis on the impact of auditors' independence on the credibility of financial statement in Nigeria. He based his results on a purposive sample of 80 firms in Nigeria which shows that the independence of an auditor affects the credibility of the financial statement. Moreover, his result also provides empirical evidence that the improvement in the credibility of the financial statement can minimize the manipulation of financial statements. Ebimobowei (2011) examines the adequacy of independence of auditors and determines whether or not the provision of non-audit services affect the independence of researcher. He collected data from documentary sources in a descriptive manner. In his findings, he reported that the 
prohibition of non-audit service by auditors to the same client does not solve the problem of corporate failure rather, there should be improved disclosure, transparency and governance around the subject of non-audit fees, policies and procedures.

Adeyemi and Akinniyi (2011) carry out a cross-sectional survey on the opinions of randomly selected lecturers of auditing, practicing auditors, stockbrokers, shareholders and managers. The outcome of their result shows that the size of audit fee is the most influencing factor capable of deterring auditors' independence in Nigeria. Their findings also proposed that the existing laws were obsolete and hence the need to update them so as to make them relevant.Adeyemi and Okpala, (2011) examine the impact of audit independence on financial reporting in Nigeria. The study aimed at investigating the interaction between audit quality and corporate financial reporting in Nigeria. The study captures the opinions of respondents including auditors, shareholders, brokers, analysts, regulators, management, academics and others users of financial information. They obtained primary data using questionnaire, while the secondary data were generated from the financial statements of forty annual reports of companies quoted on the Nigerian Stock Exchange. The study found a significant and positive relationship between audit quality and the quality of financial reporting.Oladipupo and Izedonmi (2011) examine the relationship between the audit fees and nature of audit reports of twenty-seven publicly quoted companies in Nigerian Stock Exchange between 2002 and 2006. The results of their analysisshows that the higher the audit fee the lower the auditor independence and the higher the incidence of issuing unqualified audit reports.

\section{Research Methods}

For the purpose of this study, Lagos State was considered as a case study.Due to the nature and sensitivity of this study, survey approach was adopted in conjunction with a suitable approach of data collection. A self-administeredquestionnaire was used. Documentary sources which include Company Annual Reports and Financial Statement and the Nigerian Stock Exchange Factbook for the relevant years (1999 - 2009) wereconsulted for secondary data. The population of the study consist of 205 firms involving in various sectors of the Nigerian economy particularly listed on the Nigerian Stock Exchange where only 186 firms are actively traded on the floor of Nigerian Stock Exchange. Therefore, 186 firms constitute the population for the study.The primary data was collected through two sets of self-administered questionnaires. The secondary data was gathered from published annual reports of some selected listed companies on Nigerian Stock Exchange and Fact Book for the relevant years (1999-2009).

\section{Data Analysis}

Objective One: Toinvestigate the level of compliance by quoted companies on the appointment and remuneration of auditors in Nigeria.

Table 4.1: $\quad$ Analysis of Respondents Response on the Level of Compliance by Quoted Companies on the Appointment and Remuneration of Auditors in Nigeria.

\begin{tabular}{|l|c|c|c|c|c|}
\hline \multicolumn{1}{|c|}{ STATEMENT } & \multicolumn{3}{c|}{ RESPONSES (\%) } \\
\cline { 2 - 6 } & SA & A & U & D & SD \\
\hline $\begin{array}{l}\text { The provisions in Company and Allied Matters Act (2004), as } \\
\text { amended are sufficient to ensure auditors independence in Nigeria }\end{array}$ & 4.1 & 8.7 & 3.4 & 43.1 & 40.7 \\
\hline $\begin{array}{l}\text { Virtually all listed companies in Nigeria strictly comply with the } \\
\text { provision contained in CAMA (2004) with respect to remuneration } \\
\text { and tenure of external auditor }\end{array}$ & 24.7 & 41.4 & 2.7 & 31.2 & - \\
\hline $\begin{array}{l}\text { Audit firms that provide external auditing services should not be } \\
\text { permitted to provide consulting services to the same client } \\
\text { simultaneously }\end{array}$ & 17.2 & 70.6 & 5.4 & 2.2 & 4.6 \\
\hline $\begin{array}{l}\text { Appointment of auditors by the directors (to fill a casual vacancy } \\
\text { appointment of a company's first auditors) does not affect auditors' } \\
\text { independence }\end{array}$ & 20.2 & 50.0 & 15.1 & 12.4 & 2.3 \\
\hline $\begin{array}{l}\text { Fixing of auditors' remuneration of the listed companied by the audit } \\
\text { committee (committee of directors and shareholders) can guarantee } \\
\text { auditor independence }\end{array}$ & 18.4 & 59.3 & 3.4 & 12.1 & 6.8 \\
\hline $\begin{array}{l}\text { Since auditors are paid by their clients, it is psychologically } \\
\text { impossible for an auditor to be free from bias }\end{array}$ & 19.4 & 42.1 & 8.0 & 22.0 & 8.5 \\
\hline
\end{tabular}




\begin{tabular}{|c|c|c|c|c|c|}
\hline \multirow[t]{2}{*}{ STATEMENT } & \multicolumn{5}{|c|}{ RESPONSES (\%) } \\
\hline & SA & $\mathrm{A}$ & $\mathrm{U}$ & $\mathrm{D}$ & SD \\
\hline $\begin{array}{l}\text { The provisions in Company and Allied Matters Act (2004), as } \\
\text { amended are sufficient to ensure auditors independence in Nigeria }\end{array}$ & 4.1 & 8.7 & 3.4 & 43.1 & 40.7 \\
\hline $\begin{array}{l}\text { Virtually all listed companies in Nigeria strictly comply with the } \\
\text { provision contained in CAMA (2004) with respect to remuneration } \\
\text { and tenure of external auditor }\end{array}$ & 24.7 & 41.4 & 2.7 & 31.2 & - \\
\hline $\begin{array}{l}\text { Audit firms that provide external auditing services should not be } \\
\text { permitted to provide consulting services to the same client } \\
\text { simultaneously }\end{array}$ & 17.2 & 70.6 & 5.4 & 2.2 & 4.6 \\
\hline $\begin{array}{l}\text { Appointment of auditors by the directors (to fill a casual vacancy } \\
\text { appointment of a company's first auditors) does not affect auditors' } \\
\text { independence }\end{array}$ & 20.2 & 50.0 & 15.1 & 12.4 & 2.3 \\
\hline $\begin{array}{l}\text { Section } 357(2) \text { states that "at any annual general meeting a retiring } \\
\text { auditor, however appointed shall be re-appointed without any } \\
\text { resolution being passed unless:- } \\
\text { (a) he is not qualified for re-appointment ;or } \\
\text { (b) a resolution has been passed at that meeting appointing } \\
\text { some other person instead of him; or } \\
\text { (c) he has given the company notice in writing of his } \\
\text { unwillingness to be re-appointment". } \\
\text { The above provisions imply that there is no limit to the number of } \\
\text { years auditor can serve as external auditor of a company in Nigeria. }\end{array}$ & 29.2 & 56.2 & 8.1 & 5.9 & .5 \\
\hline
\end{tabular}

\section{Source: Field Survey (2013)}

From the Table 4.5, it can be deduced that, the provisions in Company and Allied Matters Act (2004), as amended are not sufficient to ensure auditors independence in Nigeria. Secondly, virtually all the listed companies in Nigeria strictly comply with the provisions contained in CAMA (2004) with respect to remuneration and tenure of external auditors. Moreover, audit firms that provide external auditing services should not be permitted to provide consulting services to the same client simultaneously. Fourthly, fixing of auditors' remuneration of the listed companied by the audit committee (committee of directors and shareholders) can guarantee auditor independence.

\subsection{The Extent to Which Remuneration and Tenure Affect Auditors' Independence in Nigeria}

Objective Two: To examine the extent to which remuneration and tenure affect auditors' independence in Nigeria.

Table 4.2: Analysis of Respondents Response in Examining the Extent to Which Remuneration and Tenure Affect Auditors' Independence in Nigeria

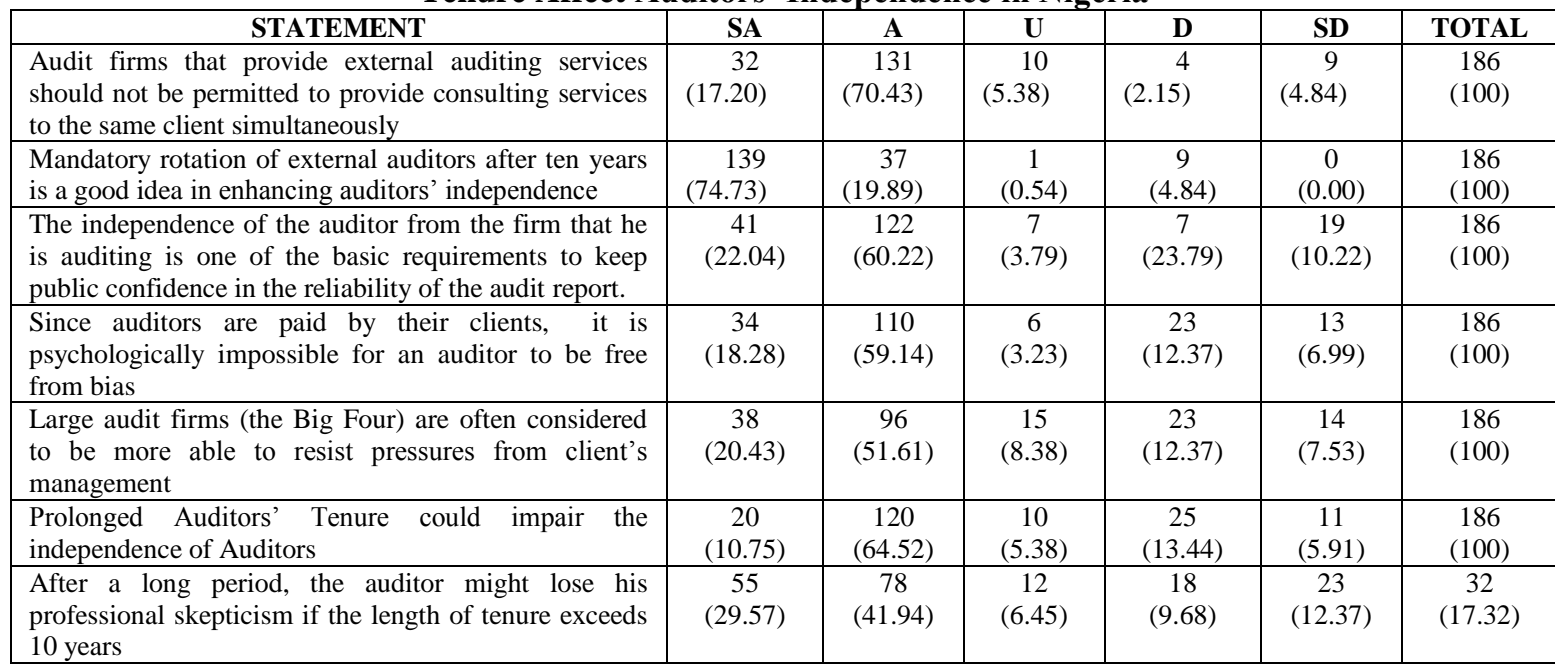

\section{* Indicates the frequency, while $(*)$ is the percentage}

Source: Field Survey (2013)

\section{Hypotheses Testing}

$\mathbf{H}_{\mathbf{0 1}}$; There is no significant relationship between quoted companies' level of compliance and, the appointment and remuneration of auditors in Nigeria. 
$\mathbf{H}_{\mathbf{a} 1}$ : There is significant relationship between quoted companies' level of compliance and, the appointment and remuneration of auditors in Nigeria.

Finding(s): From Table 4.3 below, since the chi-square calculated $\left(\mathrm{X}^{2}\right.$-cal) are greater than chi-square tabulated $\left(\mathrm{X}^{2}-\mathrm{tab}\right)$ which makes all the figures to be highly statistically significant with the probability value $=0.000$ across all pairs of variable; we reject the null hypothesis stated earlier that: there is no significant relationship between quoted companies' level of compliance and, the appointment and remuneration of auditors in Nigeria. Thus, we accept the alternative hypothesis that: there is significant relationship between quoted companies' level of compliance and, the appointment and remuneration of auditors in Nigeria.

Table 4.3: $\quad$ Chi-square Analysis table of Relationship between Quoted Companies Level of Compliance and, the Appointment and Remuneration of Auditors in Nigeria

\begin{tabular}{|c|c|c|c|c|}
\hline S/N & Relationship & Pearson Chi-Square (Value) & Pr (Value) & Remark \\
\hline $\mathbf{1}$ & ST1 vs ST2 & 190.8359 & 0.000 & Significant \\
\hline $\mathbf{2}$ & ST1 vs ST3 & 113.0273 & 0.000 & Significant \\
\hline $\mathbf{3}$ & ST1 vs ST4 & 210.5763 & 0.000 & Significant \\
\hline $\mathbf{4}$ & ST1 vs ST5 & 177.8712 & 0.000 & Significant \\
\hline $\mathbf{5}$ & ST1 vs ST6 & 210.1066 & 0.000 & Significant \\
\hline $\mathbf{6}$ & ST1 vs ST7 & 187.7719 & 0.000 & Significant \\
\hline $\mathbf{7}$ & ST2 vs ST3 & 185.4841 & 0.000 & Significant \\
\hline $\mathbf{8}$ & ST2 vs ST4 & 305.5271 & 0.000 & Significant \\
\hline $\mathbf{9}$ & ST2 vs ST5 & 180.9144 & 0.000 & Significant \\
\hline $\mathbf{1 0}$ & ST2 vs ST6 & $266 . .1957$ & 0.000 & Significant \\
\hline $\mathbf{1 1}$ & ST2 vs ST7 & 150.5363 & 0.000 & Significant \\
\hline $\mathbf{1 2}$ & ST3 vs ST4 & 314.9129 & 0.000 & Significant \\
\hline $\mathbf{1 3}$ & ST3 vs ST5 & 373.2982 & 0.000 & Significant \\
\hline $\mathbf{1 4}$ & ST3 vs ST6 & 230.9330 & 0.000 & Significant \\
\hline $\mathbf{1 5}$ & ST3 vs ST7 & 219.7090 & 0.000 & Significant \\
\hline $\mathbf{1 6}$ & ST4 vs ST5 & 280.5770 & 0.000 & Significant \\
\hline $\mathbf{1 7}$ & ST4 vs ST6 & 318.0095 & 0.000 & Significant \\
\hline $\mathbf{1 8}$ & ST4 vs ST7 & 341.2017 & 0.000 & Significant \\
\hline $\mathbf{1 9}$ & ST5 vs ST6 & 334.2689 & 0.000 & Significant \\
\hline $\mathbf{2 0}$ & ST5 vs ST7 & 323.3178 & 0.000 & Significant \\
\hline $\mathbf{2 1}$ & ST6 vs ST7 & 311.5644 & 0.000 & Significant \\
\hline
\end{tabular}

Source: Computations and Output of STATA 12 based on Author's Field Survey (2013).

$\mathbf{H}_{\mathbf{0 2}}$ : Auditors remunerations and tenure have no significant effect on auditors' independence in Nigeria.

$\mathbf{H}_{\mathbf{a} 2}$; Auditors remunerations and tenure have significant effect on auditors' independence in Nigeria.

Finding(s): From Table 4.4 below, since the chi-square calculated $\left(\mathrm{X}^{2}\right.$-cal) are greater than chi-square tabulated $\left(\mathrm{X}^{2}\right.$-tab) which makes all the figures to be statistically significant with the probability value $=0.000$ across all pairs of variables; we reject the null hypothesis stated earlier that: Auditors remunerations and tenure have no significant effect on auditors' independence in Nigeria. Thus, we accept the alternative hypothesis that: Auditors remunerations and tenure have significant effect on auditors' independence in Nigeria.

Table 4.4: Chi-square Analysis Table of the Effect of Auditors' Remuneration and Tenure on Auditors' independence in Nigeria

\begin{tabular}{|c|c|c|c|c|}
\hline S/N & Relationship & Pearson Chi-Square (Value) & Pr (Value) & Remark \\
\hline $\mathbf{1}$ & ST1 vs ST2 & 289.9532 & 0.000 & Significant \\
\hline $\mathbf{2}$ & ST1 vs ST3 & 337.7827 & 0.000 & Significant \\
\hline $\mathbf{3}$ & ST1 vs ST4 & 431.2305 & 0.000 & Significant \\
\hline $\mathbf{4}$ & ST1 vs ST5 & 381.2265 & 0.000 & Significant \\
\hline $\mathbf{5}$ & ST1 vs ST6 & 349.9617 & 0.000 & Significant \\
\hline $\mathbf{6}$ & ST1 vs ST7 & 275.2180 & 0.000 & Significant \\
\hline $\mathbf{7}$ & ST2 vs ST3 & 182.1093 & 0.000 & Significant \\
\hline $\mathbf{8}$ & ST2 vs ST4 & 287.0969 & 0.000 & Significant \\
\hline $\mathbf{9}$ & ST2 vs ST5 & 283.2770 & 0.000 & Significant \\
\hline $\mathbf{1 0}$ & ST2 vs ST6 & 344.2088 & 0.000 & Significant \\
\hline $\mathbf{1 1}$ & ST2 vs ST7 & 219.3605 & 0.000 & Significant \\
\hline $\mathbf{1 2}$ & ST3 vs ST4 & 396.8504 & 0.000 & Significant \\
\hline $\mathbf{1 3}$ & ST3 vs ST5 & 423.4123 & 0.000 & Significant \\
\hline $\mathbf{1 4}$ & ST3 vs ST6 & 311.1528 & 0.000 & Significant \\
\hline $\mathbf{1 5}$ & ST3 vs ST7 & 371.6975 & 0.000 & Significant \\
\hline $\mathbf{1 6}$ & ST4 vs ST5 & 551.2171 & 0.000 & Significant \\
\hline $\mathbf{1 7}$ & ST4 vs ST6 & 535.7718 & 0.000 & Significant \\
\hline $\mathbf{1 8}$ & ST4 vs ST7 & 353.3383 & 0.000 & Significant \\
\hline $\mathbf{1 9}$ & ST5 vs ST6 & 486.3684 & 0.000 & Significant \\
\hline $\mathbf{2 0}$ & ST5 vs ST7 & 469.7873 & 0.000 & Significant \\
\hline $\mathbf{2 1}$ & ST6 vs ST7 & 313.3623 & Survey & \\
\hline
\end{tabular}

Source: Computations and Output of STATA 12 based on Author's Field Survey (2013). 


\section{Conclusion}

While the major focus of this paper is to appraise the effects of remuneration and tenure on auditors' independence in Nigeria. Attempt was made to investigate the level of compliance by quoted companies with the provisions of the Companies and Allied Matters Act 2004 in the appointment and remuneration of auditors in Nigeria; and assess the extent to which remuneration and tenure affect auditors' independence in Nigeria.The results of the findings of the study showed thatvirtually all the listed companies in Nigeria strictly comply with the provisions contained in CAMA (2004) with respect to remuneration and tenure of external auditors. However, the provisions in Company and Allied Matters Act (2004), as amended are not sufficient to ensure auditors independence in Nigeria. Thus, fixing of auditors' remuneration of the listed companied by the audit committee (committee of directors and shareholders) can guarantee auditor independence; and audit firms that provide external auditing services should not be permitted to provide consulting services to the same client simultaneously.

Similarly, the findings of the study showed thatsince the independence of the auditor from the firm that he is auditing is one of the basic requirements to keep public confidence in the reliability of the audit report; mandatory rotation of external auditors after ten years is a good idea in enhancing auditors' independence. Reason being that,after a long period, the auditor might lose his professional skepticism if the length of tenure exceeds 10 years.

\section{Recommendations}

Based on the findings from this study, the following recommendations are proffered:

(i) There is the need for the Nigeria Financial Reporting Council and other Regulatory Bodies in line with best practices to look critically into the issue of auditor tenure and the impact on audit quality.Consequently, there should be a limit set on the number of years for which both the auditors and the clients can be in the relationship. This is to guard the occurrence of cases like that of the Cadbury Nigeria Plc.

(ii) The provisions of Companies and Allied Matters Act, 2004 can be stretched to include a section on auditors' independence for compliance.

(iii) In order to avoid the problem of those who pay the piper and dictate the tune, an independent body, like the Nigerian Financial Reporting Council should be responsible for the appointment and fixing of auditors remuneration instead of empowering the Directors to determine their remuneration as stipulated in Section 357(2) of the Companies and Allied Matters Act CAP C 20, Laws of the Federation of Nigeria, 2004.

\section{References}

[1]. Abdel-Khalid, A. (2002) Reforming Corporate Governance Post Enron: Shareholders' Board of Trustees and the Auditor. Journal of Accounting and Public Policy. Vol. 21(2) 97 - 103

[2]. Adeyemi, S. B. and Okpala, O. (2011). The Impact of Audit Independence on Financial Reporting: Evidence From Nigeria. Business and Management Review. Vol. 1 (4): 9-25, June.

[3]. Adeyemi, S.B. and Akinniyi, K.O. (2011).Stakeholders' Perception of the Independence of Statutory Auditors in Nigeria.Serbian Journal of Management 6 (2). 247-267.

[4]. Bakre, O.M. (2007). The Unethical Practices of Accountants and Auditors and Compromising Stance of Professional Bodies in the Corporate World: Evidence from Corporate Nigeria,Accounting Forum, 31(3): 277-303.

[5]. Bazerman, M., Morgan, K. and Loewenstein,G. (1997). “The Impossibility of Auditor Independence"Sloan Management Review Vol. 89, . 91

[6]. Chambers, A. (2011). Audit Market Concentration: Implications and Solutions- a Personal Perspective. A Paper Accompanying a Keynote Speech at The British Accounting and Finance Association's Auditing Special Interest Group's 21st Audit and Assurance Conference at The Institute of Chartered Accountant of Scotland, Edinburgh, 12st May.

[7]. Dabor, E.L. and Adeyemi, S.B. (2009)."Corporate Governance and Credibility of Financial Statements in Nigeria."Journal of Business Systems, Governance and Ethics, 4(1): 13-24.

[8]. DeAngelo, L.E. (1981b). “Auditor Size and Audit Quality.”Journal of Accounting and Economics Vol. 3 (1): $113-127$.

[9]. Ebimobowei, A. (2011). "Non-Audit Services and the Impairment of Auditors' Independence: A Further Examination." Pakistan Journal of Social Sciences 8 (2): . 100-107.

[10]. Evbodaghe, J.I. (2009). Global Trends in the Accountancy Profession; The Nigerian Accountant, 42(4): 36-47.

[11]. Factbook (2009) The Nigerian Stock Exchange. Lagos: The Nigerian Stock Exchange

[12]. Federal Government of Nigeria, (2004), the Companies and Allied Matters Act CAP.C20 LFN, 2004. Abuja. Federal Government Printer

[13]. Firth, M. A. (1980). Perceptions of Auditor Independence and Official Ethical Guidelines. The Accounting Review , Vol.55:451466.

[14]. Kumar, R. and Sharma, V. (2009) Auditing Principles and Practices, New Delhi: PHI Learning Private Limited.

[15]. Lennox, C. (2005). Audit Quality and Executive Officers' Affiliations with CPA Firms. Journal of Accounting and Economics Vol.39: 201-231

[16]. Mason, E. (2004). Professional Needs Rotation of Auditors Accounting Today (October): $6-8$.

[17]. Millichamp, A. H. (2002).Auditing 8th ed..London Bookpower/ELST.

[18]. Moore, D. A., Tetlock, P. E., Tanlu, L. Bazerman M. H., (2006). Conflict of Interest and the Case of Auditor Independence: Moral Seduction and Strategic Issue Cycling. Academy of Management Reviewed Vol. 31(1), 10 - 29. 
[19]. Nelson, M. W. (2006). Response: Ameliorating Conflicts of Interest in Auditing: Effects of Recent Reforms on Auditors and their Clients. Academy of Management Reviewed Vol. 31(1), 30 - 42.

[20]. Okike, E. (2004). "Management of Crises: The Response of the Auditing Profession in Nigeria to the Challenge to Its Legitimacy". Accounting, Auditing and Accountability Journal, 17(5): 705-730.

[21]. Oladipupo, A. O. and Izedonmi (2011).Propensity of Unqualified Audit Reports and Auditors' Independence in Nigeria.Tran Campus Journal of Research in National Development.Vol. 9. No 1. $440-445$.

[22]. Olagunju, A. (2011). "An Empirical Analysis of the Impact of Auditors Independence on the Credibility of Financial Statement in Nigeria.’Research Journal of Finance and Accounting. Vol 2, No 3.

[23]. Onwuchekwu, A. Erah, D and Izedonmi, F. (2012). Mandatory Audit Rotation and Audit Independence: Survey of Southern Nigeria

[24]. Otusanya, J.O. and Lauwo, S. (2010) "The Role of Auditors in the Nigerian Banking Crises." Accountancy Business and the Public Interest.Vol. 9, 159- 204.

[25]. Raiborn, C., Schorg, C.A., Massoud, M. (2006) Should Auditor Rotation be Mandatory? The Journal of Corporate Accountancy and Finance Vol. 17 (4), 37 - 49

[26]. Sikka, P., Filling, S. and Liew, P. (2009) “The Audit Crunch: Reforming Auditing”, Managerial Auditing Journal, 24 (2) . $135-155$.

[27]. Tahinakis, P. and Nicolaou, A. (2004). "An Empirical Analysis of the Independence of Greek Certified AuditorAccountant."Accounting Business and the Public Interest, 3(1): . 32-47.

[28]. U. S. General Accounting Office (2003) Public Accounting Firms: Study on the Potential Effects of Mandatory Audit Firm Rotation. November. Washington, D. C. Government Printing Office.

[29]. U.S. House of Representatives (2002). The Sarbanes-Oxley Act of 2002. Public Law 107 - 204 (H.R. 3763). Washington, D.C. Government Printing Office.

[30]. Whittington, O. and Pany, K. (2004). Principles of Auditing and Other Assurance Services. Fourteenth (ed.). New York, NY: McGraw-Hill.

[31]. Woolf, E (1986). AuditingToday, 3rd ed. New York: Prentice/Hall International, 524p. 